\title{
Termomodernization analyses of terraces located above existing apartments
}

\author{
Marek Dohojda ${ }^{1,{ }^{*}}$ Konrad Podawca ${ }^{1}$, and Joanna Witkowska-Dobrev ${ }^{1}$ \\ ${ }^{1}$ Warsaw University of Life Sciences - SGGW, Faculty of Civil and Environmental Engineering, \\ Department of Civil Engineering, St. Nowoursynowska 159, 02-776 Warsaw, Poland
}

\begin{abstract}
The paper discusses the principles of terraces design assessment with different types of insulation. It presents and compares layer systems and choice of materials in the existing terraces and modernized. Special attention was paid to the need to ensure adequate thermal insulation in areas adjacent to the balconies and terraces as well as terraces. See also the main principles of good design such structures, taking into account issues of temperature and humidity, as well as making the modernization of the terraces.
\end{abstract}

\section{Introduction}

When analyzing buildings structure the covering elements constructed traditionally as a roof trusses or as a reinforced concrete pitched flat roof $[8,13]$. According the definition "Pitched flat roof if a barrier enclosing the building from above and play a role of a roof and ceiling in terms of construction role and functionality. That means it bears the snow and wind loads, and insulate from precipitation ant temperature changes. Similar role play roofs which eliminate the temperature factor, however they do not influence the microclimate of enclosed spaces, as pitched flat roofs do" [9].

A different form of a roof is terrace. "Terrace is a pitched flat roof enclosing the building structure, or attached to it (i.e. garages), which is equipped with a cover layer and the edges are protected by a balustrade so it can be safely used" [10]. The definition "Terrace" comes from the Standard [15] where it is described as: "horizontal outer layer, classified as a roof, designed to be used by people, often protected by a balustrade".

Pitched flat roof is a multilayered barrier. Depending on principal criterion concerning its role, structure and isolation type, there are two types of pitched flat roof with a terrace cover [1]:

- traditional form, where the termo-isolation layer is located beneath the hydro-isolation layer;

- overturned form, with termo-isolation layer placed above the hydro-isolation layer.

In the present case the analyses of the traditional form will be performed. This particular terrace type is still quite common when designing detached houses or in block of flats type

\footnotetext{
*Corresponding author: marek_dohojda@sggw.pl
} 
of buildings. That is why designing and constructing terraces the following requirements need to be fulfilled [15]:

- precise determination of each terrace element practical function;

- the analyses of the structure type need to be performed;

- determine the loads deriving form destructive factors;

- complex solution for steam, thermal and water proof insulations.

\section{Overall characteristics of terrace structure}

\subsection{General requirements}

For the appropriate design of terraces there are several rules that need to be followed [1]:

- the design and construction of the terrace needs to effectively protect the spaces beneath its structural slab form the precipitation,

- the walls attached to terrace slabs also needs to be protected from water penetration,

- the outer inclination of terrace needs to be at least $1.5 \%$ ( $2 \%$ recommended form observation), that needs to be formed beneath the hydro-insulation layer,

- in traditional types, thermal-isolation layer should be layered beneath the waterproof isolation, and for overturned systems thermal layer made of non-absorbing material, needs to be placed on the hydro-isolation layer,

- the layers need to be chosen regarding health and safety rules,

- anchoring of the balustrade should not allow any damage of hydro-isolation of a terrace slab,

- constructing materials of isolation layers should be highly elastic and biological corrosion resistant,

- materials of each layer cannot affect each other, as it can drive to severe damages over time of terrace isolations,

- the hydroisolation layer requires placing non-slipping before layering overburden such as cement finishing.

\subsection{Structural terraces for terraces}

Nowaday in Poland the availability of deferent technologies for constructing metrical used as waterproof and dydro-isolation is very wide. However, when deciding on appropriate material selection the requirement's for its thickens need to be consider [3]. Usually it determines the number of covering layers. According the study [2], for isolation materials the number of layers should be as follows :

- 3 layers of glued asphalt insulation material,

- 2 layers of asphalt insulation for fiber glass welded junctions,

- 2 layers of asphalt insulation for polyester fibers welded junctions,

- 2 layers of asphalt insulation for multiple layer welded junctions,

- 2 layers of asphalt insulation with modified mass cover, for fiber glass, polyester fibers or multiple layers,

- 2 layers of self-adhesive insulation,

- layering construction film or laminate is allowed in configuration as follows:

- min 1 layer of PVC construction film,

- laminate made of hydro-isolation asphalt and asphalt-polymer mass, with fiber reinforcement of $3 \mathrm{~mm}$ thickness, on single asphalt layer,

- laminate made of hydro-isolation asphalt and asphalt-polymer mass, with fiber 
reinforcement of $2.5 \mathrm{~mm}$ thickness, on double asphalt layer,

- laminate made of polymer mass, with fiber reinforcement of thickness specified in appropriate report.

One of the main objective of waterproof systems construction is to eliminate the moisture or water being enclosed below the surfaces of isolation layer [12]. Thus the works should be performed during only dry periods, when the outside temperature does not decrease below $+5^{\circ} \mathrm{C}[10]$.

\section{Overall characteristics of terrace structure}

In the present study the terraces constructed as patched flat roofs are analyzed. Its technical condition is assessed as well as the layering in regard to thermal modernization on the base of meeting the thermal barrier isolation criterion and potential risk of vapor condensation in the space located beneath the terrace according the standard [14].

\subsection{Thermal and moisture analyses of existing terrace barrier- computation methods}

When improving the energetic quality of buildings, which mainly concerns outer barriers, there is an opportunity to increase thermal and moisture requirements. The changes and repairs will positively influence the health and safety condition of the structure $[2,5]$.

To assess housing thermal quality, the coefficient of the thermal loss through the outer ceiling barrier need to be determined. Decreasing thermal loss through appropriate housing isolation, brings direct economical benefits and support sustainable development, regarding EU Direvtive 2010/31/UE "Trias energetica" [10], and according the updated regulation ... on technical conditions to be met by buildings and their location.

To assess housing thermal quality, the coefficient of the thermal loss through the outer ceiling barrier need to be determined. Decreasing thermal loss through appropriate housing isolation, brings direct economical benefits and support sustainable development, regarding EU Direvtive 2010/31/UE "Trias energetica" [10], and according the updated regulation technical requirements buildings.

The presented example presents an actual technical condition of the terrace that requires immediate repairs - figure 1 . This is an existing technical condition of the terrace located above the apartments in a block of flats.

The onsite observation revealed such damages as:

- Lining cracks of the terrace plinths,

- Tiles loosening on the terrace due to water infiltration,

- Extensive cracks on the windowsills,

- Lack of finishing layer and no waterproof isolation on the terrace (Fig. 1),

- Lack of waterproof isolation on the junction with building wall,

- Lack of hydro-isolation on balconies door thresholds,

- Efflorescence on ceramic tile and its junctions,

- Erosion of the terrace slabs and corrosion, leakages and moistening caused by damages in windows structure.

Due to the observation listed above the is a possibility that on the ceiling of the room located beneath the terrace the vapour will condensate on the surface of the building barrier, from the inside $[16,17]$. 


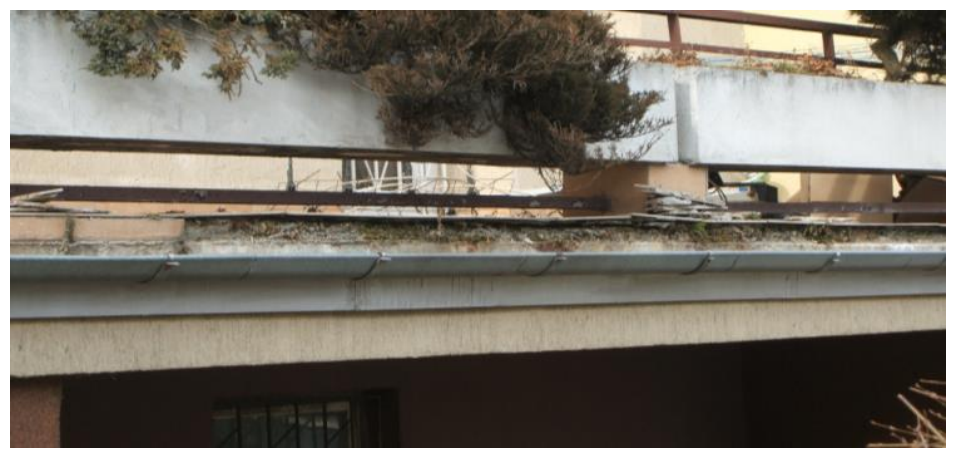

Fig 1. Example of view of the technical condition the front a terrace before modernization.

The adverse technical condition of the structure qualifies it for repairs due to number of damages caused during construction or exploitation of the building. After the site investigation and actual condition assessment, the next step will be repairing the damages. Figure 2 presents structural scheme of the terrace.

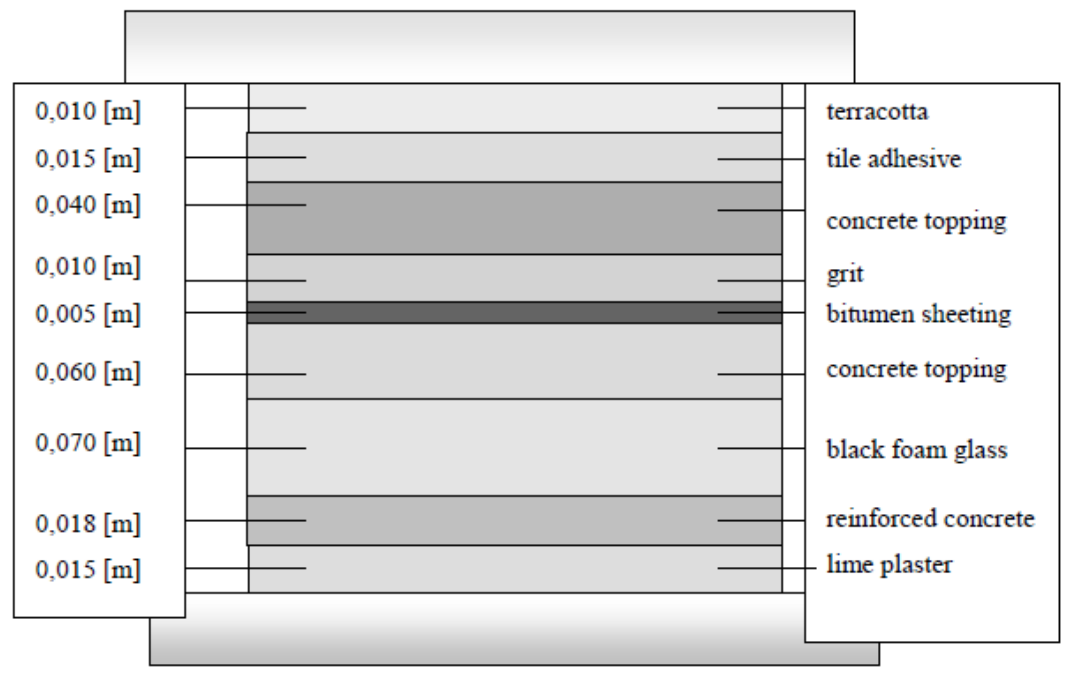

Fig. 2. The system of layering of the terrace slab.

To obtain the results computation methods applying Audytor OZC 6.1 software were used. The results were presented in figure 1, the layering of the existing terrace slab and in figure 3 which shows the layer pattern after the terrace slab modernization. As a result of the computation, thermal penetration coefficient $U$ was calculated. The analyses of results for the barrier reviled a need of thermal penetration coefficient $U$ improvement - table 1 . Thermal penetration coefficient was set to $0.700 \mathrm{~W} / \mathrm{m}^{2} \mathrm{~K}$. For the present layering the pressure distribution of vapor saturation crosses the molecule vapor saturation.

The computation showed that thermal penetration coefficient $U$ is highly overrated. The is why the decision on thermal modernization of the terrace was made, to fulfil the principal requirements $[2,6,7]$. 
Table 1. Program Auditor OZC 6.1 for the existing a terrace.

\begin{tabular}{|c|c|c|c|c|c|c|c|c|c|}
\hline \multicolumn{10}{|c|}{ Barrier analyses results t_stary } \\
\hline \multicolumn{10}{|c|}{ Technical condition requiremnts met } \\
\hline & \multicolumn{2}{|c|}{ Barrier context } & $\begin{array}{c}\theta_{i m t} \\
\mathrm{C}^{\circ}\end{array}$ & $\begin{array}{l}\theta_{\theta} \\
\mathrm{C}^{\circ}\end{array}$ & $\begin{array}{l}\Delta \theta_{i} \\
\mathrm{C}^{\circ}\end{array}$ & \multicolumn{2}{|c|}{$\begin{array}{l}\text { Scope } \theta_{i} \\
\mathrm{C}^{\circ}\end{array}$} & $\begin{array}{c}U \\
\mathrm{~W} / \mathrm{m}^{2} \mathrm{~K}\end{array}$ & $\begin{array}{c}U_{\max } \\
\mathrm{W} / \mathrm{m}^{2} \mathrm{~K}\end{array}$ \\
\hline $\mathrm{x}$ & & ROOF & 20 & -20 & 40 & & $\geq 16 \mathrm{C}^{\circ}$ & 0.700 & 0.200 \\
\hline \multicolumn{10}{|c|}{ Surface condensation $f_{r s i}$ barrier t stary } \\
\hline & $\begin{array}{l}\theta_{i} \\
\mathrm{C}^{\circ}\end{array}$ & $\begin{array}{l}\text { Calc.ulation } \\
\text { scenario } \varphi_{i}\end{array}$ & $\begin{array}{l}\varphi_{i} \\
\%\end{array}$ & \multicolumn{2}{|c|}{$\begin{array}{l}\text { Calculation } \\
\text { scenario }\end{array}$} & $\begin{array}{c}\varphi_{S i} \\
\%\end{array}$ & $\begin{array}{l}\text { Critical } \\
\text { month }\end{array}$ & $f_{R s i}$ & $f_{R B i, m a x}$ \\
\hline $\mathbf{v}$ & & Class 3 & & \multicolumn{2}{|c|}{ Mould avoid. } & 80 & January & 0.824 & 0.794 \\
\hline \multicolumn{10}{|c|}{ Barrier interlayer condensation t_stary } \\
\hline & $\begin{array}{l}\theta_{i} \\
\mathrm{C}^{\circ}\end{array}$ & \multicolumn{2}{|c|}{ Calc. scenario $\varphi_{i}$} & & & \multicolumn{4}{|c|}{ Analysis results } \\
\hline $\mathbf{v}$ & 20 & \multicolumn{2}{|c|}{ Class 3} & & & \multicolumn{4}{|c|}{$\begin{array}{l}\text { Vapour condensation present, evaporation and } \\
\text { summer periodse }\end{array}$} \\
\hline
\end{tabular}

\subsection{Thermal and moisture analyses of the terrace barrier after the thermal modernization}

After the thermal modernization the layering in the terrace slab was modified. The new pattern of layers is presented on figure 3 .

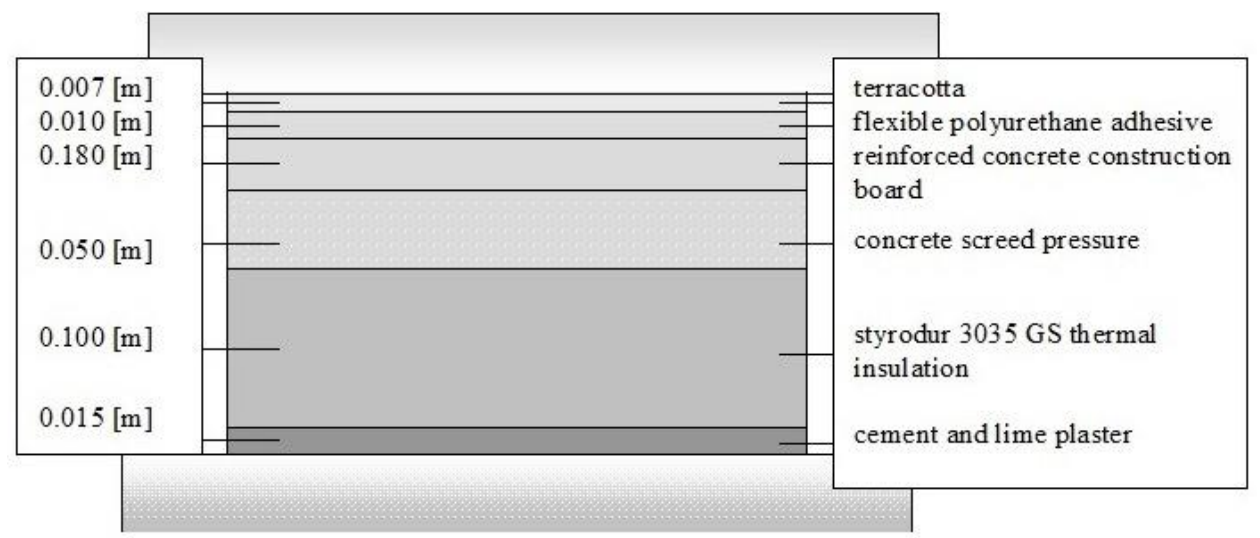

Fig. 3. The system of layering after repairing the terrace.

The modification allowed having the thermal penetration coefficient $U$ on the level of $0.300 \mathrm{~W} / \mathrm{m}^{2} \mathrm{~K}$, which means decreasing the value ca. $60 \%$. The obtained value of thermal penetration coefficient $\mathrm{U}$ meets the principal requirements. 
Table 2. Program Auditor OZC 6.1 results after modernization of the terrace.

\begin{tabular}{|c|c|c|c|c|c|c|c|c|c|}
\hline \multicolumn{10}{|c|}{ Barrier analyses results t_nowy } \\
\hline \multicolumn{10}{|c|}{ Technical condition requiremnts met wt } \\
\hline o & \multicolumn{2}{|c|}{ Barrier context } & $\begin{array}{l}\theta_{i m t} \\
\mathrm{C}^{\circ}\end{array}$ & $\begin{array}{l}\theta_{\theta} \\
\mathrm{C}^{\circ}\end{array}$ & $\begin{array}{l}\Delta \theta_{i} \\
\mathrm{C}^{\circ}\end{array}$ & \multicolumn{2}{|c|}{$\begin{array}{c}\text { Scope } \\
\mathrm{C}^{\circ}\end{array} \theta_{i}$} & $\begin{array}{c}U \\
\mathrm{~W} / \mathrm{m}^{2} \mathrm{~K}\end{array}$ & $\begin{array}{c}U_{\max } \\
\mathrm{W} / \mathrm{m}^{2} \mathrm{~K}\end{array}$ \\
\hline $\mathrm{x}$ & & ROOF & 20 & -20 & 40 & \multicolumn{2}{|c|}{$\Theta \geq 16 \mathrm{C}^{\circ}$} & 0.300 & 0.200 \\
\hline \multicolumn{10}{|c|}{ Surface condensation $\boldsymbol{f}_{r s i}$ barrier $\mathrm{t}$ _nowy } \\
\hline $\mathrm{o}$ & $\begin{array}{l}\theta_{i} \\
\mathrm{C}^{\circ}\end{array}$ & $\begin{array}{c}\text { Calculation } \\
\text { scenario } \\
\varphi_{i}\end{array}$ & $\begin{array}{l}\varphi_{i} \\
\%\end{array}$ & & $\begin{array}{l}\text { ulation } \\
\text { enerio }\end{array}$ & $\begin{array}{c}\varphi_{S i} \\
\%\end{array}$ & $\begin{array}{l}\text { Critical } \\
\text { month }\end{array}$ & $f_{R s i}$ & $f_{R i, m a x}$ \\
\hline $\mathbf{v}$ & & Class 3 & & & ld avoid & 80 & January & 0.925 & 0.794 \\
\hline \multicolumn{10}{|c|}{ Barrier interlayer condensation t_nowy } \\
\hline & $\begin{array}{l}\theta_{i} \\
\mathrm{C}^{\circ}\end{array}$ & $\begin{array}{c}\text { Calculation } \\
\text { scenario } \\
\varphi_{i}\end{array}$ & $\begin{array}{l}\varphi_{i} \\
\%\end{array}$ & \multicolumn{6}{|c|}{ Analysis results } \\
\hline $\mathbf{v}$ & 20 & Class 3 & & \multicolumn{6}{|c|}{ No vapour condensation } \\
\hline
\end{tabular}

After the modernization was accomplished the risk of vapour condensation on the barrier surface is eliminated. Moreover, due to use of a new material (Styrodur, Styrofoam of increased value of thermal absorption) and new pattern of thermal layering, the isolating role of the barrier has increased [12].

\section{Summary}

According the site investigation and computation in the first analysis it was confirmed that the risk of vapour condensating on the surface of the terrace slab from the inside is significant. After the calculation very high thermal penetration coefficient $\mathrm{U}\left(0.700 \mathrm{~W} / \mathrm{m}^{2} \mathrm{~K}\right)$ was observed. That is why the decision on thermal modernization of the terrace was made $[4,11]$.

The second analysis concerned the barrier after the modernization, the thermal penetration coefficient $\mathrm{U}$ was $0.300 \mathrm{~W} / \mathrm{m}^{2} \mathrm{~K}$ and did not reviled risk of vapour condensation on the barriers surface, the results were presented in table 2 . This is due to increase of the barriers isolation value, because of using new isolating thermal material.

\section{References}

1. B. Francke, Izolacje wodochronne tarasów i balkonów. Projektowanie i wykonywanie (Wyd. ITB, 60, 2012)

2. A. Mitzel, W. Stachurski, J. Suwalski, Awarie konstrukcji betonowych i murowych (Arkady, 1982)

3. A.M. Neville, Właściwości betonu (Wydawnictwo Polski Cement, Kraków, 2000)

4. M. Rokiel, Hydroizolacje w budownictwie, Wybrane zagadnienia w praktyce (Dom Wydawniczy Meritum, 2009)

5. K. Wiśniewski, M. Dohojda, Acta Scientiarum Polonorum, Architectura 11, 4, 59-67 (2012)

6. A. Urban, Katastrofy budowlane w 2006 i analiza katastrof w latach 1995-2006, Materiały XXIII Konferencji Awarie Budowlane, Szczecin-Międzyzdroje, 185-198 (2007) 
7. W. Płoński, J.A. Pogorzelski, Fizyka budowli (Arkady, Warszawa, 1979)

8. Praca zbiorowa, Leksykon naukowo-techniczny (WNT, Warszawa, 2001)

9. Rozporządzenie Ministra Infrastruktury (z dnia 12.04.2002) w sprawie warunków technicznych, jakim powinny odpowiadać budynki i ich usytuowanie (Dz. U z 2002 r. nr 75, poz. 690 z późn. zm.)

10. Dyrektywa 2010/31/UE Parlamentu Europejskiego i Rady Europy (z dnia 19.05.2010) w sprawie charakterystyki energetycznej budynków

11. PN-EN 13707:2006+A2:2009, ,Elastyczne wyroby wodochronne. Wyroby asfaltowe na osnowie do pokryć dachowych. Definicje i wtaściwości".

12. PN-EN ISO 13788:2013-05, „Cieplno-wilgotnościowe wlaściwości komponentów budowlanych i elementów budynku - Temperatura powierzchni wewnętrznej konieczna do uniknięcia krytycznej wilgotności powierzchni i kondensacja między warstwowa Metody obliczania".

13. PN-EN 6701-1:1994 „Budownictwo. Terminologia. Terminy ogólne”.

14. Program Audytor OZC 6.1 Firmy SANKOM Spółka z o.o.

15. M. Bratkrajc, Analiza i przyczyny nieszczelności izolacji tarasów w stropodachach tradycyjnych, praca dyplomowa (2014)

16. S. Vasiliu, Bul. Inst. Polit. Ias. LIV, LVIII, 4 (2008)

17. M.J. Carretero-Ayuso, J. de Brito, Journal of Performance 30, 6 (2016) 